\title{
MICRORGANISMOS EM ANTISSÉPTICOS E DESINFETANTES
}

\author{
Autores: \\ * Tokiko Murakawa Moriya \\ * Dorisdaia Carvalho \\ * Maria Helena Machado
}

\begin{tabular}{l|l|}
\hline RBEn/07 \\
\hline
\end{tabular}

MORIYA, T.M., CARVALHO, D. e MACHADO, M.H. - Microrganismos em antissépticos e desinfetantes. Rev. Bras. Enf.; DF, 29 :66-69, 1976.

\section{INTRODUÇAO:}

São inúmeras as possibilidades de infeç̧ōes cruzadas em hospitais. Tanto o elemento humano (pacientes, médicos, enfermeiros e outros) como o ar e os objetos inanimados de toda espécie podem ser fatores importantes na disseminação das infecçōes nos hospitais. Existem fatores que favorecem o desenvolvimento de qualquer infecção, ou sejam o organismo virulento, o indivíduo suscetível e as vias de transmissão do organismo. Sabemos que todos eles abundam o hospital.

Para se evitar a disseminação de infeç̧ōes existem procedimentos que poderāo ser usados, como: a constatação de infecção nos pacientes e no pessoal, 0 isolamento de pessoas infectadas, a imunização, as drogas antibióticas e quimioterápicas, e as técnicas limpas e assépticas.

Uma rotina permanente de combate às infecçōes afim de salvaguardar os pacientes de riscos de infecçōes que por vezes trazem conseqüências desastrosas, devem ser instituídas. Deste modo, todos devem estar conscientes de responsabilidade e assumir o seu papel na prevenção de infecçōes.

Cabe à enfermagem de modo direto observar e manter a limpeza da unidade sob sua respansabilidade, entretanto, não é raro encontrarmos técnicas e condiçōes dos materiais negligenciados.

Embora se saiba que as soluçōes de desinfetantes e antissépticos podem sofrer contaminação e acarretar infecçōes graves e, até mesmo fatais, a devida atenção não tem sido dada a esse problema na maioria dos hospitais Brasileiros (ZANON, Uriel, 1973).

- Auxiliar de ensino da Escola de Enfermagem de Ribeirão Preto,' USP.

* Professor assitente doutor da Escola de Enfermagem de Ribeirāo Preto, USP. 
MORIYA, T.M., CARVALHO, D. e MACHADO, M.H. - Microrganismos em antissépticos e desinfetantes. Rev. Bras. Enf.; DF, $29: 66-69,1976$.

$\mathrm{Na}$ ocasião em que realizamos o nosso estudo, observamos em uma clínica de um hospital de Ribeirão Preto, que antissépticos e desinfetantes do carrinho de curativo, não estavam merecendo os cuidados assépticos que consideramos de importância, ou seja:

- esterilização dos frascos antes de se colocar as soluções;

- troca de soluções;

- limitação de tempo de permanência das soluções no frasco;

- proteção do canal de drenagem da solução e o orifício de entrada do ar (suspiro).

Diante do fato, programamos este trabalho com o objetivo de verificar as condições dos antissépticos e desinfetantes no que concerne à contaminação por microrganismos.

\section{MATERIAL E METODOS}

Analisou-se 10 antissépticos e desinfetantes que compunham o arsenal dos carrinhos de curativo do posto de enfermagem de um hospital de Ribeirão Preto. Estes foram: Permangnato de Potássio; Sterylderme; Agua Oxigenada; Mercúrio Cromo; Alcool; Mertiolate colorido; Violeta de Genciana; Fucsina; Iodo e Alcool para conservação de pinça servente.

Todos esses produtos, com exceção do Alcool para conservação da pinça servente estavam acondicionados em frascos de vidro devidamente arrolhados com tampa de borracha apresentando dois orifícios. Um para drenagem da solução e outro para entrada de ar (suspiro). Em ambos os orifícios havia um canudo de vidro transfixado comunicando o interior e exterior do frasco.

De cada frasco foram colhidas 4 amostras, obedecendo a um intervalo regular de 8 dias entre uma colheita e outra.

Uma quantidade de $10 \mathrm{ml}$ de cada frasco era então colhida diretamente do frasco para um tubo de ensaio estéril, tomando-se o cuidado de desprezar a porção inicial do jato da solução.

A semeadura foi realizada com alça padronizada (RIGATTO E SOLE-VERNIN) com a finalidade de quantificar $o$ número de microrganismos viáveis por $\mathrm{ml}$ de solução.

O meio de cultura utilizado foi agar infusão de coração mais sangue.

A técnica da semeadura consistiu em flambar a alça, esfríá-la na porção mais superficial da amostra, previamente homogeneizada por movimentos de rotação. Um aliquota era em seguida colhida do fundo do tubo e colocada no centro da placa contendo meio de cultura. A fim de espalhar a amostra e cobrir inteiramente a superfície do meio de cultura, a semeadura foi orientada em 4 direções diferentes.

A leitura foi realizada após 24 horas de incubação em estufa a $37^{\circ} \mathrm{C}$, em aercbiose, deste modo os microrganismos crescidos foram apenas os aeróbicos.

As colônias crescidas na placa foram examinadas e contadas, e a este número multiplicou-se o fator 800 para obtermos o número de microrganismos viáveis por ml. Este fator 800 foi utilizado em virtude do volume transportado pela alça corresponder respectivamente a $\frac{1}{800}$ do $\mathrm{ml}$ ou seja $1,25 \times 10$ do $\mathrm{ml}$.

\section{RESULTADOS}

Dos antissépticos e desinfetantes estudados, 6 apresentaram crescimento de microrganismos aeróbicos. Foram identificados Bacilus Subtilis, Sarcina e Stafilococus. Em vista de ser o nosso propósito verificar as condições assépticas das soluções, os resultados aqui apresentados são em relação a quantidade de microrganismos sem qualificação dos mesmos (Tabela I). 
MORTYA, T.M., CARVALHO, D. e MAChaDO, M.H. - Microrganismos em antissépticos e desinfetantes. Rev. Bras. Enf.; DF, 29 : 66-69, 1976.

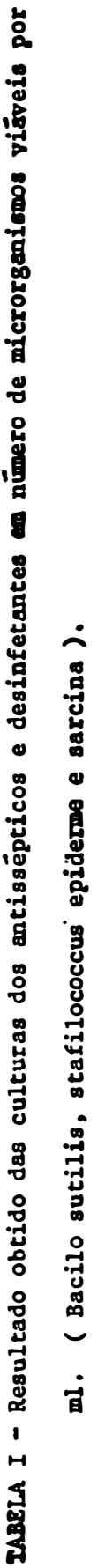

\begin{tabular}{|c|c|c|c|c|}
\hline 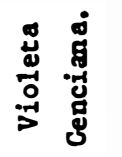 & 1 & 1 & 1 & ' \\
\hline 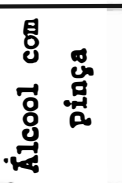 & $\begin{array}{l}+8 \\
8 \\
8\end{array}$ & $\begin{array}{l}8 \\
\text { ठे } \\
\dot{8}\end{array}$ & $+_{1}$ & 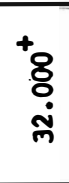 \\
\hline 象 & 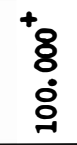 & $t_{1}$ & 1 & 1 \\
\hline 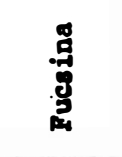 & 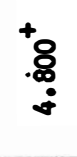 & $\begin{array}{l}+ \\
\\
8 \\
8\end{array}$ & $\begin{array}{l}+\dot{8} \\
8 \\
\\
\end{array}$ & 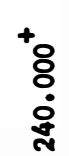 \\
\hline 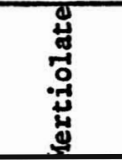 & ' & $\begin{array}{l}+ \\
8 \\
8 \\
7\end{array}$ & $\pm !$ & 1 \\
\hline 官 & 1 & 1 & +1 & 8 \\
\hline 遮 & 1 & $\begin{array}{l}+ \\
.8 \\
8\end{array}$ & $t_{1}$ & 1 \\
\hline$\overbrace{\pi}^{N}$ & 1 & $\begin{array}{l}8 \\
8 \\
8 \\
\end{array}$ & $\begin{array}{l}\text { 78 } \\
\dot{8} \\
\dot{0} \\
\end{array}$ & $t_{1}$ \\
\hline 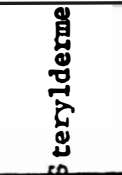 & 1 & $+_{1}$ & : & 1 \\
\hline 总 & 1 & $t_{1}$ & 1 & 1 \\
\hline & : & \%ั & में & \% \\
\hline
\end{tabular}


MORIYA, T.M., CARVALHO, D. e MACHADO, M.H. - Microrganismos em antlssepticos e desinfetantes. Rev. Bras. Enf.; DF, 29 : 66-69, 1976.

As soluçōes de Permanganato de potássio, sterylderme e álcool foram completadas uma vez e apresentaram-se sem contaminação em todas as amostras. Quanto a violeta de gengiciana, o seu conteúdo não fol completado e também nāo apresentou contaminaçāo. $O$ mercúrio cromo após a adição de outra porção de solução não apresentou crescimento de microorganismos, o mesmo ocorrendo com o mertiolate, lodo e a água oxigenada. $O$ álcool usado para conservação da pinça servente após a troca da solução apresentou-se isento de microrganismos no dia da substituiçāo mas apresentou contaminação na colhelta posterior. A fucsina apresentou um aumento progressivo do número de microrganismos viáveis com o decorrer do tempo.

\section{DISCUSSAO E CONCLUSAO}

A ausência de contaminação em alguns produtos leva-nos a pensar que a fórmula quantitativa desses produtos tenha favorecido o não desenvolvimento de microrganismos.

Por outro lado encontramos antissépticos inicialmente não contaminados $e$ que a partir de um dado momento tornou-se colonizado por microrganismo, o que nos faz acreditar que a fórmula quantitativa do produto nāo adequada somada a negligência de cuidados as- sépticos tenha levado ao favorecimento da contaminação.

Aqueles produtos que tiveram seus resultados negativados após os frascos terem sido completados, e outros, mesmo após esse processo, continuarem com presença de microrganismos, atribuimos responsabilldades à quantidade de produto, recolocado no irasco, embora reconheçamos o não controle dessa variável.

Apesar do não controle de algumas variáveis neste trabalho, ficou evidente que antissépticos e desinfetantes podem ser veículos importantes de infecção, portanto devendo merecer maiores cuidados em relação à fórmula quantitativa e cuidados assépticos.

RALWUNGS (1970), na Conferência Internacional sobre infecçōes nosocomiais (ATLANTA, E.U.A.) disse: Parece-me irracional tentar evitar infecçöes hospitalares por uma variedade de métodos caros e complicados e delxar que estafilococos, pseudomonas, Klebsielas, Salmonelas e outros microsganismos velculados em medicamentos e cosméticos infetem pacientes hospitalizados. Da mesma forma diremos em relação a antissépticos e desinfetantes.

Pretendemos realizar novas experiênclas no mesmo local onde esta fol realizada, forem com as condiçōes estabelecidas atualmente, ou seja, merecendo os cuidados assépticos que consideramos de importåncia e controlando malor número de variáveis.

\section{BIBLIOGRAFIA}

1. RAIJWNGS, O.L. - Contamination of therapeutic agents - Proo. of. Int. nos. Conf. C.DC. 1970, p. 241-245.

2. RIGATO, H. e SOL-VHRNIN, C. - As alças padronizadas na avaliação quantitativa de bacteriuria. Separata
Revista Paulista de Medictina, 71 (10): 199-210, out. 1967.

3. ZANON, Uriel. - Fundamentos para o controle das infecçóes adquiridas em hospital. Semestre Terapeutico, n.0 28, dezembro de 1973, p. 2 - 12. 